\title{
Tax Challenges Facing Developing Countries
}

\author{
Richard M. Bird*
}

* Professor Emeritus, University of Toronto.

Inaugural Lecture of the Annual Public Lecture Series of the National Institute of Public Finance and Policy, New Delhi, India, March 12, 2008 


\title{
Tax Challenges Facing Developing Countries 1
}

\author{
Richard M. Bird
}

Taxes matter. We all know we need them to pay for public services. But most of us complain about them -- exercise our "voice" -- and often try to dodge them -- to "exit" -- when we can. ${ }^{2}$ Those who design and implement tax systems, like those who try to escape them, for the most part consider themselves to be eminently 'practical' people responding to the world around them as they see it. As John Maynard Keynes (1936, 384-85) once said, however, "practical men, who believe themselves to be quite free from any intellectual influences, are usually the slaves of some defunct economist.....soon or late, it is ideas, not vested interests, which are dangerous for good or evil." While true to some extent, at least when it comes to taxes this dictum both unduly flatters economists and puts too little weight on interests and other factors. Tax policy everywhere is shaped not only by ideas and vested interests but also by changing economic conditions, administrative constraints and technological possibilities, and, especially, the political institutions within which these factors are at play. ${ }^{3}$

Developing countries are no different from others: ideas, interests, and institutions determine tax policy. It is of course difficult to generalize about taxation in "developing countries" as a group. Such countries encompass such a wide spectrum -- from small fragile and fragmented post-conflict states like Liberia and Afghanistan to large well-established and rapidly growing countries

1 Although some parts of the present document draw on a recent paper with a somewhat similar title (Bird and Zolt 2008) the two papers take essentially different approaches to the subject. The approach taken in the present paper is developed at more length and from additional perspectives in Bird (forthcoming) which is focused more on the problems of countries in subSaharan Africa. This written version of the lecture has benefited from comments by Govinda Rao and discussions with a number of other colleagues in India and is consequently, I hope, a bit more attuned to the situation in large countries like India that are growing rapidly but unevenly.

2 See the famous study by Hirschman (1970) of the interplay of exit (economic responses) and voice (political responses).

3 See, for examples, Daunton (2001, 2002) on the U.K., Gillespie (1991) on Canada, Steinmo (1993) on Sweden, the UK and the US, Lieberman (2003) on South Africa and Brazil, and IDB (2006) on Latin America more generally. Tax technology is not discussed in detail in this paper: for a recent treatment, see Bird and Zolt (2007). 
like Brazil, China, and India -- that there may seem to be few "tax challenges" that they face in common. The 'best' tax system for any country reflects its economic structure, its capacity to administer taxes, its public service needs, and its access to such other sources of revenue as aid or oil. In addition it must also take into account such nebulous but important factors as 'tax morale', 'tax culture', and, perhaps above all, the level of 'trust' existing between people and their government. ${ }^{4}$

Despite the resulting variety of tax systems and possibilities found in the developing world, however, in one very important sense all developing countries do face the same basic tax challenge: how to meet public spending needs by raising revenue in a way that is not only economically sustainable but also conducive to the political survival of those making policy decisions.

Fortunately or otherwise, there is no shortage of those willing to set universal fiscal goals and standards for developing countries as a group. Almost half a century ago, for example, Nicholas Kaldor (1963), fresh from his recent exposure to India's tax system, argued that for a country to become 'developed' it needed to collect in taxes 25-30 percent of GDP. More recently, perhaps having noted that most developing countries (like India) remain well short of Kaldor's target, the UN Millennium Project (2005) was somewhat less ambitious in advising developing countries that on average they needed to mobilize only an additional 4 percent of GDP in tax revenue beyond their current average level of about 18 percent. $^{5}$

Most developing countries have consistently failed to meet such targets. A few fast-growing Asian countries such as India have managed to reach and even exceed the UN-prescribed 4 percent of GDP increase in tax ratio in the early years of this century but it is by no means clear that these new higher levels will be sustainable. ${ }^{6}$ In most developing countries the tax ratio has changed surprisingly little in recent decades. The belief that some seem to hold that developing countries can increase their tax take simply through more vigorous

\footnotetext{
${ }^{4}$ For introductory discussions of the three factors mentioned, see, respectively, Frey (2002), Edling and Nguyen-Thahn (2005), and Bergman (2002).

${ }^{5}$ For a recent summary of tax levels and structures in countries grouped by income level, see Fox and Gurley (2005). Of course, 'revenue' is not identical to (or limited to) tax revenue but such niceties are neglected here. Bird, Martinez-Vazquez and Torgler (2006) analyze both revenue and tax ratios in developing countries and find no great differences in most instances.

${ }^{6}$ For instance, as Poirson (2006) shows, general government revenues as a share of GDP have been surprisingly constant over time in India.
} 
collection efforts is particularly naïve. ${ }^{7}$ There is more to improving tax effort than simply exhorting countries to try harder.

Of course some who tell developing countries they should collect more taxes have not been reluctant to tell them how to do it. In the post-World War II period, for instance, most commentators assumed that a highly progressive personal income tax (sometimes with marginal rates ranging up to 60 or 70 percent -- or, as in India, even as over 90 percent) buttressed by a substantial corporate income tax (often at 50 percent or so) constituted the ideal tax system. Both revenue and redistribution goals, it was argued, could be achieved by imposing high effective tax rates on income, essentially because the depressing effects of taxes on investment and saving were considered to be small. ${ }^{8}$ Consumption taxes were grudgingly accepted as necessary for revenue purposes, but the sooner such levies were replaced by decent income taxes the better. ${ }^{9}$ No one talked about local taxes since all the action was at the central government level. Nor did anyone worry much about the international context since tax policy was considered a domestic affair. In short, to exaggerate only a bit, the conventional wisdom at the time was that all developing countries needed to do to solve their fiscal problems was, as the UN Millennium Project still seems to assume, in the words of Kaldor (1963) simply to "learn to tax" -- by which he meant to tax in a properly progressive fashion.

The world has changed, however, and so have ideas about taxation. As a recent IMF study (Norregaard and Khan 2007) correctly notes, there remain huge gaps in the evidence with respect to the effects of taxes and "herd thinking" in tune with the fashion of the day continues to be as influential in taxation as in most areas of public policy. Nonetheless, many economists now think that high tax rates not only discourage and distort economic activity but are also largely

${ }^{7}$ One of the best documented cases in which better administration increased revenues markedly in a short time was Argentina's rapid expansion (from 13 to 23 percent of GDP) over the the 198992 period. Morrisset and Izquierdo (1993) estimated that about two-thirds of this increase was attributable to improved administrative effort. As in other cases, however, subsequent experience in Argentina demonstrated how difficult it is to sustain such increases over time (Bergman 2003). When improved technology or increased administrative effort expands revenues, in many instances it appears that political pressures soon dampen or even fully offset any resulting net increase in tax ratios (Martinez-Vazquez 2001).

${ }^{8}$ Indeed, an extra bonus of high rates was considered to be that they made it easier to lead balky private investors by the very visible hand of well-designed fiscal incentives into developmentally productive channels: for a review of the unrewarding experience with such incentives, see Bird (2000).

${ }^{9}$ Kaldor (1956) famously proposed an expenditure tax for India, but he did so not because he was against taxing 'ability to pay' but because he thought the expenditure base came closer to measuring 'spending power' than did income as conventionally defined for tax purposes. His similar proposal for Ceylon (Kaldor 1960) -- now Sri Lanka -- was actually implemented but never amounted to much and was soon abolished (Goode 1961). 
ineffective in redistributing income and wealth. Indeed, though reflecting more the competitive international environment of recent decades than the persuasiveness of economists, income tax rates on both persons and corporations have been sharply reduced around the world. In Latin America, for example, the average tax rate on corporations fell from 41 percent in 1985 to 29 percent in 2003 and the top rate on personal income from 51 to 28 percent. Over this period, collections from direct taxes in Latin America increased by only 5 percent (from 4.0 to 4.2 percent). Since trade taxes also declined, the tax share of GDP in the region would actually have declined had it not been for a substantial (70 percent) increase in VAT revenues. Indeed, as elsewhere in the world, VAT has now become the mainstay of the revenue system in Latin America owing both to rate increases - the regional average VAT rate rose from 11 to 15 percent in 1985-2003 -- and to broader bases and improved administration. ${ }^{10}$

The combination of declining taxes on international trade as a result of import liberalization and WTO adherence with increased competition for foreign investment has motivated similar changes in tax structures in developing countries in other regions as well. However, policy-makers in some countries seem to have been more reluctant than those in Latin America to cut income tax rates and to put more emphasis on domestic consumption taxes such as VAT perhaps because they see such suggestions as little more than code for "increase taxes on the poor." Even those that did follow the Latin American model for the most part have seldom offset the potential revenue losses of income tax rate reductions by base expansions. ${ }^{11}$

No matter what any country may want to do with its tax system, or what anyone might think it should do from one perspective or another (ethical, political, or developmental), what it does do is always constrained by what it can do. Economic structure, administrative capacity and political institutions all limit the range of tax policy options. Nonetheless, even in the most constraining situations some options almost always exist. The consensus of most fiscal experts, almost regardless of political stance,$^{12}$ seems to be that the best way for developing countries to respond to the tax challenges they face, in the current jargon, in expanding their "fiscal space" along the revenue axis (IMF 2006) -- are

${ }^{10}$ See Lora and Cardenas (2006) The effect of base and administrative changes is evident because 'VAT productivity,'defined as VAT revenues as a percentage of GDP divided by the (standard) VAT rate rose substantially in the region over the period. More refined calculations approximating the VAT base more closely show similar results (Bird and Gendron 2007).

11 In contrast, developed countries that cut corporate rates usually did expand the tax base in compensation (Norregaard and Khan 2007).

${ }^{12}$ For three recent surveys from different perspectives that basically reach the conclusion stated in the text, see Toye (2000), Moore (2004), and Heady (2004). 
essentially three: (1) broaden tax bases (especially of consumption taxes), (2) reduce rates (especially of income taxes), and (3) improve tax administration. Although in reality each of these three pathways to reform is interdependent, in the next few sections I shall briefly consider each in turn.

\section{Broadening Tax Bases}

Most discussion of taxation in developing countries seems to assume, as it were, that "unto each a base is given." If the tax base is indeed 'given' then the only policy issue would be how best to exploit it -- for example, by reducing exemptions and bringing non-payers into the tax net. Such measures are indeed important in most countries, but this focus is too narrow. Tax bases are not simply 'given' to governments: they can be 'grown' - or destroyed - through the manner in which a given tax burden is collected. For example, taxes may discourage, or encourage, the 'formalization' of the economy, or they may foster or discourage the growth of such 'tax handles' as imports, or they may be used to shape and direct economic growth into particular channels in a variety of ways and for a variety of purposes.

In the hurly-burly of politics and the technical wonderland of fiscal analysis it is all too easy to overlook such 'developmental' effects of tax policies. Yet in the long run the manner in which (and from whom) taxes are collected may affect not only growth and distribution but also the future level and mix of revenues itself. ${ }^{13}$ These long-run effects of policy decisions affecting both tax design and tax administration need more attention.

Consider, for example, four questions that are often posed with respect to the challenges facing tax policy in developing countries:

- $\quad$ Should more reliance be put on consumption than on income taxes?

- $\quad$ Are broader tax bases always better than narrower bases?

- Should tax policy be designed to reduce the size of the 'informal economy'?

- What should be done with tax incentives?

\footnotetext{
${ }^{13}$ For recent distinct but related analyses relevant to this theme, see Emran and Stiglitz (2005), Auriol and Warlters (2005) and Gordon and Li (2005). In a different framework, Poirson (2006) makes much the same point in the context of India.
} 
The conventional answers of most fiscal experts -- if not always of governments -- to these questions are straightforward:

- Consumption taxes are better.

- So are broader bases.

- Every effort should be made to tax the informal sector.

- Tax incentives are almost always a bad idea.

But do all these answers hold up when considered from the perspective of the long-run development of 'tax base policy'?

In many developing countries personal income taxes often amount to little more than taxes on labor income and are equivalent to consumption taxes paid in advance. At the same time, although little revenue is received from capital income, both income and consumption taxes in practice often impose high marginal effective rates on investment and hence discourage growth. ${ }^{14}$ Such taxes deliver neither equity nor growth. What a tax is called -- income or consumption -- matters less than how it really works.

On the other hand equity and growth are sometimes surprisingly compatible. For example, not only must the poor consume to be productive but societal disaffection with the inequities accompanying growth often seems to require some degree of visible fiscal correction in order to sustain growthfacilitating policies. The first of these points suggests that a good VAT in many developing countries may sometimes be one that excludes a significant fraction of the consumption of poor people. ${ }^{15}$ Broader bases are not always better. Poverty alleviation through the fiscal system is primarily a tax for expenditures, not taxes. But it is also important not to make the poor even poorer through taxes. At the very least, heavy selective taxes on items that constitute major consumption expenditures for poor people should be avoided. ${ }^{16}$

14 See Poirson's (2006) description of the current Indian tax system for a depressingly good example.

15 In the case of Jamaica, for example, exempting only five narrowly-defined items cut the VAT burden on the lowest 40 percent of the income distribution in half (Bird and Miller 1989). In principle, a more inclusive tax base combined with a targeted subsidy would of course be preferable but such refinement is not attainable in the circumstances of many developing countries. As Bird and Gendron (2007) suggest, it may be better for a variety of reasons to subject such items to a reduced rate rather than to exempt them completely. Of course, such decisions should be made only after detailed consideration of the circumstances prevailing in the country in question.

16 As Hughes (1987) notes, for example, taxing fuel correctly can be difficult in countries like Indonesia or India in which petroleum products (in this case, kerosene or paraffin) are an essential consumption item for the poorest people. As mentioned earlier, the option of using the tax system to deliver income support to low-income people as in some developed countries 
On the other hand, the second point mentioned above suggests that there may also be an important continuing role in most fiscal systems for the income tax -- the "mirror of democracy" as one fiscal history labeled it (Webber and Wildavsky1986). Most developing countries thus probably need both income and consumption taxes but they need the right kind of each: the details of design and administration matter the lot, although this is not the place to go into such details. ${ }^{17}$

A tax system concerned to facilitate growth should both reduce the cost of operating in the formal sector ${ }^{18}$ and increase the cost of operating in the informal sector. Imposing higher taxes on traditional agriculture is usually difficult both politically and administratively and it may not always be equitable, but it is likely conducive to growth by shifting resources away from the traditional agriculture sector -- a development that always and everywhere accompanies growth (Bird 1974). Much the same can be said about presumptive taxes on informal sector activities even though such taxes are often so badly designed and operated that they are horizontally inequitable and seldom yield much revenue (Bird and Wallace 2004). When countries have large informal sectors even a bad tax on a 'good' base may be a good idea (Auriol and Warlters 2005). ${ }^{19}$

Conventional wisdom also seems right about what should be done with virtually all tax incentives: eliminate them. Despite their continuing popularity almost everywhere, tax incentives are usually redundant and ineffective: they reduce revenue and complicate the fiscal system without achieving their stated objectives. Even to the limited extent that some incentives are effective in inducing investors to behave differently than they would have done in response

requires both that the tax administration is efficient and that most people file tax returns. Neither condition is satisfied in most developing countries. However, it is possible that technological improvements such as smart mobile phones and the Internet may soon make both transfers and taxes more easily "personalized" even in remote areas of poor countries: for further discussion, see Bird and Zolt (2007).

17 For discussion of general and selective consumption taxes see, respectively, Bird and Gendron (2007) and Cnossen (2005).

${ }^{18}$ Consider, for example, the recent World Bank publication Paying Taxes 2008 in which India rests near the bottom (165 out of 178 countries considered) compared to, say, Singapore which ranks second in the world with respect to the costs to formal business of complying with the tax system. If India is serious about growth, something clearly needs to be done to simplify its tax system and improve its tax administration -- a conclusion that also emerges strongly from the recent studies of compliance costs carried out at the National Institute of Public Finance and Policy (e.g. Chattopadhyay and Das Gupta 2002).

19 Or it may not, if, as is sometimes the case (World Bank 2003), the result of creating a "simplified" tax system intended to entice people from the informal sector into the formal sector is instead to encourage formal sector entrepreneurs to pretend that they too are small in order to hide in the simplified sector while at the same time erecting an additional barrier to firms moving from the small (tax-favored) sector to the normal tax system. 
to market signals the result is often inefficient, diverting scarce resources into less than optimal uses (McLure 1999).

The political (and sometimes even theoretical) appeal of twisting the tax system into a collection of clever gimmicks that seem to do something for any good cause of which one can think is obvious. So, alas, is the grim reality of the bad things that experience has again and again demonstrated tend to happened once one starts down the tempting road. Loading more and more objectives on the tax system through incentives opens the door to inefficiency and inequity and reduces the chances that the tax system can achieve its main objective of adequately funding essential public sector activities. Tax incentives improve economic performance only if government officials are better able to decide the best types and means of production than are private investors. Since observation suggests strongly that people are likely to spend 'other people's (taxpayers) money' with considerably less care than they do their own, this proposition seems inherently implausible. Excessive use of tax incentives complicates administration, facilitates evasion and encourages corruption. Once created, concessions usually prove hard to remove and tend to be enlarged at the initiative of taxpayers who lobby for more concessions or simply redefine existing concessions in unforeseen and presumably undesired ways. Get rid of them.

If one cannot simply eliminate tax incentives, I have elsewhere suggested three simple rules to reduce the damage that may be caused by poorly-designed and implemented incentives: keep them simple, keep records, and evaluate the results (Bird 2000). Alas, very few developing countries have managed to follow even such basic rules as these: the political advantages of ambiguity seem always to outweigh the potential social gains from transparency. ${ }^{20}$

\section{Lowering Tax Rates}

For many developing countries the challenge is not so much whether to increase revenues -- in most cases they must do so if they are to grow and prosper -- but rather how to do so. Essentially, there are only three possibilities: raise rates, expand bases, and improve administration. Raising rates within the

${ }^{20}$ Apart from introducing tax expenditure budgets, for which there is much to be said (Surrey and McDaniel 1985), developed countries seldom do much better but of course the social costs of such mistakes tend to be relatively less important for the rich than the poor. 
existing system is the most obvious approach, and it is often also the most politically acceptable approach. Unfortunately, it is almost always the least economically desirable solution. Raising rates when traditional tax bases are not expanding, new bases can shift abroad, and administration is weak is unlikely to increase revenue much if at all. Even if revenues do increase, so may both inequity and inefficiency.

Distortions associated with taxation increase (broadly) with the square of the tax rate, so inefficiency definitely increases with increased rates, particularly rates affecting economically mobile factors and actors such as foreign investors. Horizontal inequity may also increase because only those few unfortunates inextricably trapped within the tax system bear the burden. When those who comply are penalized and those who cheat escape, a country is not on the path to building a sustainable revenue system. Moreover, since it is often easier to increase taxes on politically weaker segments of society, even vertical inequity may be exacerbated by rate increases in some instances.

Of course, taxes themselves are not a cost but simply a mechanism for transferring resources from private to public use. However, taxes do impose real economic costs that reduce the resources available for other public or private purposes. Developing countries -- where resources are by definition scarce can least afford such waste and should strive to keep such costs as low as possible in order to free resources for socially desired objectives.

The resources used in administering and complying with taxes (or, for that matter, evading them) are real economic costs: they reduce the ability of the economy to provide goods and services. In addition, taxes change the relative prices businesses and individuals confront and hence alter decisions to work, to save, and to invest. The result in most cases is to reduce output and welfare. ${ }^{21}$

21 There are of course exceptions. First, when taxes are 'lump sum' - i.e. the tax burden is the same regardless of behavioral responses - there are no distortionary effects. But such taxes are of no importance in the real world. Second, to the extent that taxes fall on economic rents payments to factors above those needed to induce them into the activity concerned -- they may not affect economic activity. Well-designed taxes on natural resources and land, for example, may thus to some extent produce revenue without economic distortion. Finally, some taxes may not only create no distortions in economic behaviour but may even induce desirable behaviour. Certain environmental levies, for example (even such crude proxies such as taxes on fuel), may to some extent have such effects. "Good" taxes - those with no bad economic effects - should of course be exploited as fully as possible, but most revenue needed to finance government inevitably comes from less 'harm-free' sources and hence gives rise to efficiency costs. 
These efficiency losses from taxation are real and sometimes substantial. ${ }^{22}$ However, they are not directly visible: they arise essentially because something does not happen or happens in some other way than it would have in the absence of the distortionary tax. Output that is not produced is output (and potential welfare) lost but it is seldom politically visible. Nonetheless, good tax policy in developing countries requires designing design taxes to minimize such adverse outcomes -- keeping such costs as low as possible while also achieving revenue, growth, and distributional goals as effectively as possible. This is no small task.

To the extent that efficiency costs of taxation result from a rational policy decision to redistribute income through the fiscal system a country may of course decide that the price is worth paying. After all, fairness is a key issue in designing any tax regime. Even so, the costs of taxation can generally be reduced by shifting to consumption taxes (especially VAT) instead of income taxes. Nonetheless, some have recently suggested that 'growing' governments in developing countries on the basis of VATs rather than income taxes is a bad idea on both distributive and efficiency grounds. ${ }^{23}$

It is thus worth considering briefly three questions:

- First, are even the most nominally progressive income taxes in developing countries very redistributive? Without going into detail, the evidence seems clear: the answer is - not much. ${ }^{24}$

- Second, are VATs in developing countries inevitably regressive? The answer is - not always or necessarily. ${ }^{25}$

- And third, are there circumstances in which a 'good' VAT may be better in distributive terms than a 'bad' income tax? Unsurprisingly, in light of my answers to the first two questions, there may indeed be such circumstances, depending as usual upon the details of both the country and the two taxes.

22 The lowest estimates of the efficiency costs of taxes for developed countries are at least 20-30 percent of revenues collected, and much higher estimates (ranging well over 100 percent) are common in the literature (Auerbach and Hines 2002). While few such empirical studies exist for developing countries, some recent evidence (Warlters and Auriol 2005) suggests that the efficiency costs of taxation appear to be of the same order of magnitude.

${ }^{23}$ See, for example, Emran and Stiglitz (2005). For further discussion of a few of the many complex points touched on (or skipped over) in this section, see Bird and Zolt (2005).

${ }^{24}$ For a nice explanation of the rationale for this conclusion, see Harberger (2006). For useful summaries of studies on the quantitative incidence of taxation in developing countries see Chu, Davoodi and Gupta (2000) and Gemell and Morrissey (2003), and for well-taken skepticism about the assumptions underlying most such studies see Shah and Whalley (1990).

25 For examples and discussion, see Bird and Gendron (2007). 
Take the example of a country with a large shadow economy. Income taxes do not reach this sector - and indeed appear to be associated with its expansion (Schneider and Klinglmaier 2004). In contrast, to some extent a VAT functions like a presumptive tax on the informal sector. The reason is because VAT credits are available only to registered firms so that those operating in the shadow sector are taxed when they purchase formal-sector commodities as they almost always do to some extent for both business and consumption purposes ${ }^{26}$ Increasing income taxes often discourages the expansion of firms in the formal sector both by taxing them directly and by taxing their employees in contrast, increasing VAT tends to make life in the formal sector relatively more attractive than the informal alternative-- subject to the important proviso that the tax is not so perversely and badly administered as to raise the entry barriers to entering the formal sector too high, as unfortunately seems to have happened in some countries. $^{27}$

If combined with increased excises on such important higher-income consumption goods as motor vehicles, the substitution of indirect for direct taxes may in some instances even prove to be more progressive than relying more heavily on a personal income tax that affects only a limited group of formal sector wage earners and discourages the expansion of the formal sector. On both distributional as well as efficiency grounds, there may thus sometimes be much to be said both for broad-based consumption taxes like VAT and for a limited set of excise taxes as important components of the revenue system - as indeed they already are in most developing countries. But there are also good reasons for keeping direct taxes on both income and property in the tax mix as well. To maintain and grow a state, the tax system must tap into growing sectors of the economy, and a mildly progressive personal income tax is one way of ensuring that state revenues get their fair share. Properly applied, both income and property taxes may play a role in 'state-building'. ${ }^{28}$ Sustainable tax policy needs

${ }^{26}$ For an important study along these lines, see Glenday and Hollinrake (2005); see also Keen (2006).

${ }^{27}$ An example appears to be Ukraine (World Bank 2003). The uncomfortably close ranking of India and Ukraine in terms of the compliance costs of paying taxes in the latest World Bank (2008) study is cause for concern. Bangladesh, which ranks lower than either, may well be another example. The argument in Emram and Stiglitz (2005) that VAT may discourage formalization may perhaps be valid in some extreme cases depending on important details of tax structure and tax administration that they do not explore in detail but it certainly should not, on the evidence, be unduly generalized.

${ }^{28}$ The case for property taxes is developed at length in Bird and Slack (2004) -- although the present unimportance of such taxes in developing countries is set out clearly in Bahl and Martínez-Vazquez (2007). The general point made in the text emerges in different contexts in various recent studies: see, for example, Sokoloff and Zolt (2005) and Hoffman and Gibson (2004) as well as the general discussion and case studies in Brautigam, Fjeldstad and Moore (2007). 
to be accepted as fair by those affected. Since automobiles and big houses are more visible than income, the more effectively such items are taxed, the better. Finally, corporate income taxes are needed to buttress personal income taxes, to ensure an equitable share of the returns on cross-border investment, and to tap economic rents at least to some extent (Bird 2002). For every tax, there is a reason.

\section{Improving Tax Administration}

Reaping revenues from tax rate changes (whether up or down) requires effective tax administration. Raising revenues through base expansion requires even better administration. New taxpayers must be identified and brought into the tax net and new collection techniques developed. Such changes take time to implement. The best tax policy in the world is worth little if it cannot be implemented effectively. What can be done to a considerable extent inevitably determines what is done. One cannot assume that whatever policy designers can think up can be implemented or that any administrative problems encountered can be easily and quickly remedied. How a tax system is administered affects its yield, its incidence, and its efficiency. Administration that is unfair and capricious may bring the tax system into disrepute and weaken the legitimacy of state actions.

Good tax administration is a difficult task even at the best of times and in the best of places. Conditions in few developing countries match these specifications. How revenue is raised - the effect of revenue-generation effort on social capital, equity, the political fortunes of the government, and the level of economic welfare may be more important from many perspectives than how much revenue is raised. The private costs of tax compliance as well as the public costs of tax administration must be taken into account. Assessing the relation between administrative effort and revenue outcome is by no means simple: it is important, for example to distinguish the extent to which revenue is attributable to the active intervention of the administration rather than its relatively passive role as the recipient of revenues generated by other features of the system. Improving administrative efforts and outcomes is not impossible but it is neither easy nor quick. ${ }^{29}$

Experience around the world demonstrates that the single most important ingredient required for effective tax administration is clear recognition at high

${ }^{29}$ For detailed discussions, see Bagchi, Bird, and Das-Gupta (1995), Gill (2000), McLaren (2003) and Bird (2004) well as the case studies in Gillis (1989), Bird and Casanegra (1992), Thirsk (1997), and Das-Gupta and Mookherjee (1998). 
political levels of the importance of the task and willingness to support good administrative practices -- even if political friends are hurt. Few developing countries have been able to leap this initial hurdle. ${ }^{30}$ Frequently, urged by international agencies or simply desperate to get more revenues, countries have from time to time launched frantic efforts to corral defaulters or to rope in new victims without hurting politically powerful interests -- and also usually without providing the time, resources and consistent long-term political support needed to do the job. Such efforts are doomed to failure. Collecting taxes efficiently and effectively without fear or favor is especially difficult in countries that are politically fragile. Without such efforts, however, no viable long-term tax system can be created.

If the political will exists, the techniques needed for effective tax administration are not secret: have a clear strategy; keep it simple; treat taxpayers as clients; chase down defaulters; keep a tight check on corruption; and use available technology wisely. Sound use of such IT approaches as withholding, information reporting, web-based client focused interfaces with the private sector, and value chain analysis and monitoring -- all activities going on all the world in both private and, increasingly public sectors -- can be enormously effective in reducing corruption, curbing evasion and improving revenue yields. To be effective, however, such technological approaches need to be implemented effectively: new technology to some extent may compensate for common human failings but in the end its successful implementation inevitably depends heavily on the effective utilization of human capacities. In practice, to date technological solutions for tax administration problems in developing countries remain more hopes than realities with a few notable exceptions such as Chile and Singapore. Nonetheless, increasingly technology appears to offer potentially promising paths to at least partial solutions in many developing countries (Bird and Zolt 2007).

\section{The Political Economy of Taxation}

Tax policy decisions are not made in a vacuum. Nor are they made by a benevolent government. Instead, they are the outcome of complex social and political interactions between different groups in society in an institutional context established by history and state administrative capacity. Taxation is not simply a

${ }^{30}$ See, for instance, the telling comparison in Bergman (2003) of Argentina, which conspicuously has not leapt this hurdle, and Chile, which has. As IDB (2006) notes, there is still much we do not understand about why Chile has been able to do so much in terms of improving tax administration. As Bergman (2003) shows, however, the willingness of Chile's leaders - of very different political persuasions - to support effective administration stands out. 
means of financing government; it is also a very visible component of the social contract underlying the state. Citizens are more likely to comply with tax laws if they accept the state as legitimate and credible and are to some extent both willing to support it and afraid of what will happen to them if they don't.

Improving tax outcomes thus depends in large part upon how different political groups perceive proposed changes and how they react to these perceptions. In this sense, major tax reform is thus always and everywhere "an exercise in political legitimation" (Lledo, Schneider, and Moore 2003). Those who will have to pay more must be convinced that they will get something worthwhile for their money. Those who do not want to pay more must not be able to block reform and, in the end, must be willing to go along without taking to the hills in revolt or fleeing the country. Those who will have to implement the reform must also support it or at least not actively sabotage it. And of course politicians have to see sufficient support to warrant putting reform not only on the agenda but on the ground.

Reforming taxes is always a one-off operation in the sense that it occurs in the unique circumstances of a particular country at a particular time. ${ }^{31}$ Nonetheless, some seem to believe that there must be some simple solution to be found somewhere else in the world that can replace the seemingly unending problems and process of negotiation found in their own country. Examples of such magic solutions currently floating around the world are flat taxes, simplified presumptive regimes for small business, and semi-autonomous revenue authorities, to mention only three. ${ }^{32}$

Much can indeed be learned from studying how different countries have coped with tax reform: the solutions reached may be different but the basic problems that must be faced are often rather similar. How one country dealt with a problem may provide useful hints on how another may do so. ${ }^{33}$ Comparative analysis of tax reform experience around the world, like formal tax theory, can never provide a complete answer for any particular country. But it can help.

Most studies of tax reform experiences understandably focus on the substance of reform. A more fundamental question, however, is not what should be taken into account in developing a tax reform proposal but rather how tax

${ }^{31}$ Much of what follows relates only to 'major' tax reforms (Bird 2004a). Many countries constantly "reform" their tax systems by altering rates, redefining bases, and adding and clarifying interpretations to existing law, and it is not always a simple matter to tell when such 'technical changes' constitute a major reform but this issue is not discussed further here.

32 Some substantive reform proposals are discussed in more detail in Bird (forthcoming). Space precludes going into detail on these matters in the present paper.

33 Bird and Slack (2007) apply this approach to the case of property tax reform, for example. 
reform should be approached. ${ }^{34}$ Careful and comprehensive attention to institutional arrangements for tax reform will not only improve the quality of the reforms proposed, it will also increase the likelihood of their adoption and successful implementation. All too many abortive "reform" experiences in all to many countries demonstrate that to do a better job countries need to pay adequate attention to such basics as developing more adequate capacity to draft tax legislation and to gather and analyze data relevant to tax reforms as well as developing the procedural systems and administrative capacity to implement them. Above all -- and far too neglected -- is the critical need to 'sell' reforms not only to those who must approve them (politicians), but also to those who must administer them (officials), to those who will discuss them in public (the policy community), and, most importantly, to those who must endure them (the business community and the public). ${ }^{35}$

When it comes to tax reform, "ownership" matters. So does leadership. So does a coherent strategy, and of course adequate resources both to develop good ideas and especially to implement them effectively. Good tax policy planning involves economists, lawyers, administrators, and - never to be forgotten - adequate discussion with taxpayers, tax practitioners, and tax agents. Building up adequate institutional capacity in the tax field along all these lines, both inside and outside government, is critical to being able to adapt policies to changing circumstances -- to give them the robustness and resiliency needed for sustainability. Of course even the best planning and best implementation will not produce useful results unless there is also adequate political leadership, careful attention to building the necessary political coalitions, and close attention to the perceived needs of citizens as aggregated through parties, interest groups, and what is now often called civil society. Even the best product will not sell unless it is properly marketed. Tax reform, which in developing countries almost inevitably embodies increases for some, is inherently a hard sell. In the end, tax reform always and everywhere is an exercise in practical politics. Successful tax reform is never easy. But it can be achieved -- if countries really want to do so. ${ }^{36}$

${ }^{34}$ Of course even the best process for studying and developing reform proposals will never be enough to bring about good policy changes in the absence of a coherent strategy, continuing support from above, and an acceptable level of administration: see the interesting discussion in IDB (2006).

35 The need to get business on side reflects not only the importance of business decisions for economic growth and the importance of direct taxes on business such as taxes on business property and corporate income taxes. It also arises from the critical role that business plays as the effective tax collector for such other taxes as withheld taxes on wages, interest and dividends and sales and excise taxes.

${ }^{36}$ See Thirsk (1997) and Das-Gupta and Mookherjee (1998) for case studies of successes. 
A precondition for a major change in the country's tax system is often a change either in the political balance or in economic circumstances. In normal times a 'good' tax reform may be like a 'good' seat belt law: if everything else stays the same, lives will be saved --the tax ratio will increase. But things do not stay the same: some people drive faster when they are belted in -- tax administration effort may diminish and concessions to favoured groups multiply. ${ }^{37}$ The result that is that tax ratios -- like death rates from road accidents after the introduction of a seatbelt law -- often change little even after major tax reform. Countries appear to achieve an equilibrium position with respect to the size and nature of their fiscal systems that reflects the balance of political forces and institutions and then to stay there until 'shocked' into a new equilibrium by political upheaval or external economic pressure.

Ideas on the relevant balance between taxes and society forged over the first half of the $20^{\text {th }}$ century have changed in many countries, as evidenced by the death of death taxes in developed countries $^{38}$ and the limited success of developing countries in achieving the high levels of income taxation to which many of them aspired in the post-colonial period (Bird and Zolt 2005). Although reality in terms of both tax levels and the distribution of tax burdens has changed much less in most developing countries, attitudinal and environmental changes are clearly influencing current thinking about tax policy everywhere.

For the relevant decision-makers in any country to make the right decisions, however - 'right' in the sense that they reflect people's real preferences as closely as practically feasible -- everyone involved, not just decision-makers but also those whose fate is being decided, must be as aware as possible of the relevant consequences. One key to sustainable good fiscal outcomes is often, for example, to link expenditure and revenue decisions as transparently as possible. ${ }^{39}$ For a country to have a better tax system-better in the sense of giving the people what they want-it must first have a better political system in the sense of one that transmutes citizen preferences into policy decisions as efficiently as possible. "Democracy," as Churchill once said, "is the worst form of Government except all those other forms that have been tried from

${ }^{37}$ For an interesting example, see the discussion of Mexico in Martinez-Vazquez (2001).

${ }^{38}$ For a neat explanation of this trend, encompassing changes in both economic structure and income inequality, see Bertocchi (2007).

39 I am aware of the extent to which this statement may seem like heresy to those raised in the 19th century Gladstonian budgetary framework in which most of us still live. For further discussion of particular forms of expenditure-revenue linkage, see Bird (2001) on decentralization, Bird (2005) on project financing, and Bird and Jun (2007) on earmarking. 
time to time." ${ }^{40}$ Neither 'representation without taxation' nor 'taxation without representation' provides a sound basis on which to erect a fiscal system that will be both economically and politically sustainable in the long run.

Of course, the foregoing is somewhat idealistic but what is clear is that whether countries are democratic or not, taxation is always and everywhere a contested concept. Some pay and some do not. Some pay more than others. Some receive compensating services, some do not. Such matters are-and in democratic states, can be-resolved only through political channels, messy though such channels usually are. Indeed, history suggests that the need to secure an adequate degree of consensus from the taxed is one of the principal ways in which, over the centuries, democratic institutions have spread in some parts of the world. ${ }^{41}$ Sustainable tax systems require a high degree of popular compliance, and for such compliance to be sustainable the tax system must reflect in some real sense the basic values of at least a minimum supporting coalition of the population. ${ }^{42}$

A central problem in many developing countries, for instance, not least those like India that have been growing rapidly in recent years, is clearly inequality. A key, and related, governance problem in many of the same countries is lack of accountability to the governed by the governing. A better tax system may prove critical to the solution of both problems. For example, revenue reforms that link taxes and benefits more tightly -- such as decentralization -- may help accountability -- though not necessarily reduce inequality. ${ }^{43}$ On the other hand, reforms that replace highly regressive and

40 This quotation actually had a somewhat different implication in its original context, but nonetheless seems largely right even if one's main concern is growth: as Lindert $(2004,344)$, concludes, history tells us that "the average democracy has been better for economic growth than the average autocracy...."

41 See for example Sokoloff and Zolt (2005). No non-dictatorial government in this age of information and mobility can long stay in power without securing a certain degree of consent from the populace, not least in the area of taxation. State legitimacy thus rests to a considerable extent on what Levi (1988) called the 'quasi-voluntary compliance' of citizens with respect to taxation.

42 Daunton $(2001,2002)$ shows that a great deal of attention was paid to precisely this task in Britain, with quite different tax levels and tax mixes being found most suitable to the "consensusmaintaining' objective over the years. Gillespie (1991) tells a similar (more economics-focused) tale for Canada. Lieberman (2003) to some extent tells similar stories with respect to Brazil and South Africa. For a stimulating general model of the balancing of political and economic concerns in formulating and implementing tax policy in a democratic setting, see Hettich and Winer (1999). Tridimas and Winer (2004) in effect extend this framework to non-democratic settings.

${ }^{43}$ Another such reform is earmarking (Bird and Jun 2007), but this too may, instead of improving matters worsen them if it captured by a particular interest, as may happen all too easily even in 
inelastic excises by a less regressive and more elastic VAT may reduce inequality-especially of course if the increased revenues are invested in growthfacilitating activities such as education and infrastructure. ${ }^{44}$

From a normative perspective -- at least from my normative perspective -the key function of taxes in developing countries is to provide (non-inflationary) funding for pro-poor and pro-growth spending programs, particularly on developing human capital. ${ }^{45}$ As I have recently argued at length elsewhere, the best way to achieve this goal in most countries is likely through a relatively broad-based and relatively non-distortionary consumption tax like VAT, precisely as conventional wisdom says -- although perhaps not the precise VAT suggested by that wisdom (Bird and Gendron 2007).

What any country actually does with its tax system, however, is inevitably determined in the first instance by political and not economic calculations ${ }^{46}$ Countries vary enormously in the effectiveness and nature of their political systems. Some may be close to 'failed states' in which institutions are so ineffective that it does not matter much what they attempt to do: it will not work. Others may be 'developmentalist' and wish to use their fiscal systems as part of a relatively dirigiste interventionist policy. Still others may be more laissez-faire and disposition. Some may be more populist, some more elitist, some more predatory.

The dominant policy ideas in any country (about equity and fairness, efficiency, and growth), like the dominant economic and social interests (capital, labor, regional, ethnic, rich, poor), and the key institutions, both political (democracy, decentralization, budgetary) and economic (protectionism, macroeconomic policy, market structure), interact in the formulation and implementation of tax (and budgetary) policy. Uniform results are unlikely to emerge from this always boiling cauldron, with its different mixes of ingredients and highly variable cooking times in each country. The changing interplay of

developed and democratic countries. There is no such thing as a free lunch when it comes to institutional design.

44 Note that one implication of this argument is that relevant analysis of the incidence of policy changes must consider both sides of the budget: as Break (1974) noted, the 'differential' tax analysis beloved of economists (and illustrated by almost all extant incidence studies) is usually not the most relevant approach for policy purposes.

45 Growth-facilitating human capital activities such as education are probably the best way to reduce inequality in most countries, but some direct support activities such as minimal cash transfers are likely always to remain necessary for those unable to take advantage of such opportunities.

${ }^{46}$ Of course, as Hettich and Winer (1999) develop in detail, political and economic factors are often interdependent. See also the extensive theoretical and empirical literature surveyed in Persson and Tabellini $(2000,2002)$. 
ideas, interests, and institutions affects both the level of taxation and its structure. Indeed, as Joseph Schumpeter (1954) noted long ago, and as an increasing number of political scientists have recently come to realize, taxation is one of the clearest arenas in which to witness the working out of these complex forces.

Viewed in long-term perspective, few developing countries have as yet completed even the earlier parts of the long cycle that produced the (more or less) redistributive and (more or less) growth-facilitating fiscal states now found to varying extents in most developed countries. ${ }^{47}$ There is no inexorable historical law that decrees developing countries must similarly undergo a long preparatory period during which the idea of the desirability and even necessity of a larger state and at least a modestly progressive fiscal (tax + expenditure) system becomes part of the social framework. Still, it seems fair to say that whatever their goals may be many governments in developing countries are in dire straits. Even those countries that have reached relatively safe harbors politically with a sustainable degree of legitimacy and stability are often in an economically precarious situation. The budget is politically and economically constrained. Life is difficult. Nothing can be done. Such conclusions are easy to reach in many countries: but they also offer too much a counsel of despair and too easy an excuse to avoid making needed, and possible, decisions.

Even in the most hopeless situation something can usually be done to improve matters. Taxation is a bone of contention in every country. It may therefore seem a bit odd to argue that most countries would be better off if there were even more informed public dispute about such matters. However, unless and until an adequate degree of political consensus on what should be done is achieved, no significant tax changes are likely to be made in reality no matter what new laws may be put on the books. To a considerable extent the main tax challenge facing many developing countries is essentially that there is as yet no implicit "... social contract between governments and the general population of the kind that is embedded in taxation and fiscal principles and practices in politically more stable parts of the world" (Lledo, Schneider, and Moore 2004, 39).

Like today's newspapers, history tells us that such principles do not become embedded either painlessly or quickly. The few substantive suggestions that I have made above to help developing countries face their basic tax challenge -- such as better VAT administration on a broader base --are of course already the stuff of countless existing reports. As an expert myself I am delighted

47 Compare the different, but parallel, stories told by Lindert (2003) and Alesina and Angeletos (2003) about how different developed countries have reached quite different fiscal equilibria. Why should uniform outcomes be expected in the much more heterogeneous developing world? 
to be able to conclude that many countries would be better off if they did more of the good things that experts advise. The real question, however, is: why have so many done so little?

A recent study of Latin America suggested, perhaps somewhat wistfully, that if countries wish to improve their tax systems they should "...improve political institutions in ways that broaden and deepen social contracts. For example, create more responsive and less clientelistic political parties, more cohesive and less polarised party systems, and improved capacity of civil society to monitor government and participate in tax debates (Lledo, Schneider, and Moore 2004, 40)." I agree: as I said earlier, there can be no good taxation without good representation. But how useful is it to advise a country that it should be something other than what it is?

In the end, if any country needs or wants better tax policy or administration, it can have it: the answer largely lies in its own hands. Even those who want to do the right thing, however, can often use help in finding out just what is right and how it can best be done. It is always easy for those not playing a game to give advice to those who are trying to play it, but it is seldom useful to do so. Those outside politics -- and perhaps particularly foreigners -who wish to foster better sustainable tax systems in developing countries can generally put their efforts and resources to better use if they play in the right game. That game is not the short-term political game in which policy decisions are made. Instead, it is the long-term game of building up the domestic institutional capacity both within and outside governments to articulate relevant ideas for change, to collect and analyze relevant data, and of course to assess and criticize the effects of such changes as are made.

Such long-term 'institution-building' activities are seldom immediately rewarding. They are certainly out of fashion. ${ }^{48}$ It always seems more appealing and immediately productive both to outside advisors and often to governments themselves to establish 'benchmarks' for success, to support this particular organizational change here (revenue authority) and that new technology (computerization) there -- and all too often concessions, reliefs and incentives all over the place -- than it does to help countries acquire the institutional tools they need to reach better decisions on their own. It is always tempting to believe that simple 'one-size-fits-all' approaches can provide quick (but sustainable!) answers

\footnotetext{
${ }^{48}$ In this depressing scenario, the National Institute of Public Finance and Policy in India is a rare exception. Of course even the best "think tanks" are not enough: as Yoingco (1976) shows, for many years the Philippines had by far the best developed and institutionalized tax planning process in Asia, and indeed in some respects perhaps in the developing world. Unfortunately, in the absence of a propitious political environment the results in terms of better policy were not very evident in the Philippines.
} 
to the many complex problems inherent in reforming tax policy in difficult environments. It is tempting. But it is wrong.

\section{Conclusion}

I have argued that what any developing country does to reform either its tax structure or its tax administration generally depends less on the economics of taxation than on the politics of taxation. From the perspective of someone outside the policy arena in any particular country, I have also suggested that the best way in which experts and aid agencies can help developing countries meet the many tax challenges they face is by assisting them to create the human and institutional capacity they need in order to do so. ${ }^{49}$

Some may think that these conclusions are so vacuous as to provide little if any practical operational guidance to would-be tax reformers. I might, for example, instead have expounded at length about the need for countries like India that are increasingly engaged in international business to take more seriously the task of fitting their tax systems into the changing international setting -- or else trying to change that setting in the first place. I have not done so, however, in part because for too many years fiscal experts like me have landed at airports around the world carrying briefcases and laptops crammed with 'one-size-fits-all' solutions. Such oversold 'silver bullets' as revenue authorities, improved information technology (IT), European-type VATs, flat taxes and the like have missed the target so often in so many countries, that it seems more than time for those seriously interested in improving tax policy and especially tax outcomes in developing countries to face up to the fundamental question: how best to encourage and facilitate countries in the critical task of building the capacity they need to find their own solutions in their own ways ${ }^{50}$

\footnotetext{
49 I should perhaps note that there are a number of things most developed countries could do to their own tax systems and their aid policies to make the lives of policy-makers in developing countries simpler. For example, it is astonishing to see agencies that commonly urge countries to strengthen their revenue systems at the same time insisting that all their aid and technical assistance to such countries completely escapes domestic taxation. Much could also be said about the lack of international fiscal forums directly responsive to the needs of developing countries. However, such issues are not the focus of this paper.

50 It may be, as Clark (2007) has recently argued in a notably pessimistic appraisal of the prospects for most developing countries, that the time will not be "ripe" for such actions can be effective in many countries for more years than most of us care to contemplate but such deep questions cannot be considered further here.
} 
A corollary of this argument is that any advice on policy specifics that may accompany such capacity-building assistance should be delivered not from on high but only on request. Lenders concerned with fostering particular outcomes may of course still wish to impose fiscal conditions of various sorts, and those seeking money may sometimes choose to accept them, but one must not confuse such exchanges of threats and promises with the development and implementation of sustainable fiscal reforms.

No doubt such games will continue to be played for years to come. However, those who really want to help developing countries meet the tax challenges they face can likely best assist them by improving the institutional framework within which they operate. ${ }^{51}$ Improving the transparency and understanding with which fiscal issues are discussed by all relevant players, both domestic and international, is not a boring bit of institutional building to be gotten out of the way before getting down to the "real business" of tax reform. On the contrary, 50 years of experience tells us that, precisely because the great ongoing tax game is an integral part of political reality in all countries, aiding and abetting such capacity-building activities is in the long run, and perhaps even in the short run, the real "real business" of tax reform. Moreover, this may be the only feasible way which outsiders may perhaps be able to assist at least some developing countries to implement the meaningful and substantial tax reforms many of them will need in order to meet the challenges of the 21 st century.

${ }^{51}$ For a prescient but largely ignored argument along these lines, see Mclntyre and Oldman (1975). 


\section{References}

Alesina, A.and G. Angeletos (2003) "Fairness and Redistribution: U.S. versus Europe," Working Paper 9502, National Bureau of Economic Research, MA, February.

Auerbach, A. J. and J.R. Hines, Jr. (2002) "Taxation and Economic Efficiency," in A.J. Auerbach and M.Feldstein, eds., Handbook of Public Economics, 3 ( Amsterdam: North-Holland).

Auriol, E. and M.Warlters (2005) "Taxation Base in Developing Countries," Journal of Public Economics, 89: 625-46.

Bagchi, A., R.M. Bird, and A. Das-Gupta (1995) "An Economic Approach to Tax Administration Reform," Discussion Paper No. 3, International Centre for Tax Studies, University of Toronto, November.

Bahl, R.W. and J. Martinez-Vazquez (2007) "The Property Tax in Developing Countries," Working Paper, Lincoln Institute of Land Policy, July.

Bergman, Marcelo (2002) "Who Pays for Social Policy? A Study on Taxes and Trust," Journal of Social Policy, 31 (2): 289-305.

Bergman, Marcelo (2003) "Tax Reforms and Tax Compliance: The Divergent Paths of Chile and Argentina," Journal of Latin American Studies, 35:593-624.

Bertocchi, G. (2007) "The Vanishing Bequest Tax: The Comparative Evolution of Bequest Taxation in Historical Perspective," IAZ DP No. 2578, Institute for the Study of Labor, Bonn, January.

Bird, R.M. (1974) Taxing Agricultural Land in Developing Countries (Cambridge, Mass.: Harvard University Press).

Bird, R. M. (2000) "Tax Incentives for Investment in Developing Countries," in G. Perry, J. Whalley, and G. McMahon, eds., Fiscal Reform and Structural Change in Developing Countries (2 vols.; London: Macmillan for International Development Research Centre), 1, 201-21.

Bird, R.M. (2001) Intergovernmental Fiscal Relations in Latin America: Policy Designs and Policy Outcomes (Washington: Inter-American Development Bank). 
Bird, R.M. (2002) "Why Tax Corporations?" Bulletin for International Fiscal Documentation, 56 (5): 194-203.

Bird, R.M. (2004) "Administrative Dimensions of Tax Reform," Asia-Pacific Tax Bulletin, 10 (3): 134-50.

Bird, R.M. (2004a) "Managing Tax Reform," Bulletin for International Fiscal Documentation, 58 (2): 42-55.

Bird, R.M. (2005) "Evaluating Public Expenditures: Does It Matter How They are Financed?" in Anwar Shah, ed., Fiscal Management. Public Sector Governance and Accountability Series (Washington: World Bank).

Bird, R. M. (forthcoming) "Tax Challenges Facing Developing Countries: a Perspective from outside the Policy Arena." Unpublished draft paper.

Bird, R.M. and M. Casanegra de Jantscher, eds. (1992) Improving Tax Administration in Developing Countries (Washington: International Monetary Fund).

Bird, R.M. and P-P. Gendron (2007) The VAT in Developing and Transitional Countries (Cambridge University Press).

Bird, R.M. and J. Jun (2007) "Earmarking in Theory and Korean Practice," in Stephen L.H. Phua, ed., Excise Taxation in Asia. A Publication of the Centre for Commercial Law Studies, Faculty of Law (Singapore: National University of Singapore).

Bird, R.M., J. Martinez-Vazquez and B. Torgler (2006) "Societal Institutions and Tax Effort in Developing Countries," in J. Alm, J. Martinez-Vazquez and M.Rider, eds., The Challenges of Tax Reform in a Global Economy (New York: Springer).

Bird, R.M. and B.D. Miller (1989) "The Incidence of Indirect Taxation on LowIncome Households in Jamaica", Economic Development and Cultural Change, 37 (2, 1989): 393-409.

Bird, R.M. and E. Slack (2004) International Handbook of Land and Property Taxation (Cheltenham, UK and Northampton, MA: Edward Elgar).

Bird, R.M. and E. Slack (2007) "Taxing Land and Property in Emerging Economies: Raising Revenue...and More?" in G.K. Ingram and Y-H. Hong, eds., Land Policies and Their Outcomes (Cambridge, MA: Lincoln Institute of Land Policy), pp. 204-33. 
Bird, R.M. and S.Wallace (2004) "Is It Really so Hard to tax the Hard-to-Tax? The Context and Role of Presumptive Taxes," in J. Alm, J.Martinez-Vazquez and S. Wallace, eds., Taxing the Hard-to-Tax: Lessons from Theory and Practice (Amsterdam: North-Holland).

Bird, R.M. and E.M. Zolt (2005) "Redistribution via Taxation: The Limited Role of the Personal Income Tax in Developing Countries," UCLA Law Review, 52 (6, 2005): 1627-95.

Bird, R.M. and E.M. Zolt (2007) "Technology and Taxation in Developing Countries: From Hand to Mouse," Paper presented at Conference on Technology, Privacy and the Future of Taxation, Washington, D.C., October.

Bird, R.M. and E.M. Zolt (2008) "Tax Policy in Emerging Countries," Environment and Planning C: Government and Policy, 26(1): 73-86.

Brautigam, D., O. Fjeldstad, and M. Moore (2007) Taxation and State-Building in Developing Countries (Cambridge UK: Cambridge University Press).

Break, G.F. (1974) "The Incidence and Economic Effects of Taxation," in A. Blinder et al., Economics of Public Finance (Washington DC: Brookings Institution).

Chattopadhyay, S. and A. Das Gupta, "The Compliance Cost of the Personal Income Tax and its Determinants," National Institute of Public Finance and Policy, New Delhi, 2002.

Chu, K., H. Davoodi, and S. Gupta (2000) "Income Distribution and Tax and Government Social Spending Policies in Developing Countries," Working Papers No. 214, UNU/WIDER, December.

Clark, G. (2007) A Farewell to Alms: A Brief Economic History of the World (Princeton University Press).

Cnossen, S., ed. (2005) Theory and Practice of Excise Taxation: Smoking, Drinking, Gambling, Polluting and Driving (Oxford: Oxford University Press).

Das-Gupta, A. and D. Mookerjhee (1998) Incentives and Institutional Reform in Tax Enforcement (New Delhi: Oxford University Press).

Daunton, M. (2001) Trusting Leviathan: The Politics of Taxation in Britain 17991914 (Cambridge: Cambridge University Press). 
Daunton, M. (2002) Just Taxes: The Politics of Taxation in Britain 1914-1979 (Cambridge: Cambridge University Press).

Edling, Herbert and David Nguyen-Thanh (2006) "Taxes and Culture - Tax Reforms for Sustainable Development" (2006) Fiscal Studies No. 5, Public Finance and Administrative Reform Studies, GTZ, Eschborn.

Emran, M. S. and J.E. Stiglitz (2005) "On Selective Indirect Tax Reform in Developing Countries," Journal of Public Economics, 89: 599-623.

Fox, W.F. and T. Gurley (2005) "An Exploration of Tax Patterns around the World," Tax Notes International, February 28: 793-807.

Frey, Bruno S. (2002) The Role of Deterrence and Tax Morale in Taxation in the European Union. Jelle Zijlstra Lecture 1, Netherlands Institute for Advanced Study in the Humanities and Social Sciences.

Gemmell, N. and O. Morrissey (2003) "Tax Structure and the Incidence on the Poor in Developing Countries," Centre for Research on Economic Development and International Trade Research paper No. 03/18, University of Nottingham, October.

Gill, J.B.S. (2000) A Diagnostic Framework for Revenue Administration (Washington: World Bank).

Gillespie, W.I. (1991) Tax, Borrow, and Spend: Financing Federal Spending in Canada 1867-1990 (Ottawa: Carelton University Press).

Gillis, M., ed. (1989) Tax Reform in Developing Countries (Durham NC: Duke University Press).

Glenday, G. and D. Hollinrake (2005) "Assessment of the Current State of VAT Implementation in SADC Member States," November.

Goode, R. (1961) "Taxation of Saving and Consumption," National Tax Journal.14: 305-21.

Gordon, R. and W. Li (2005) "Tax Structure in Developing Countries: Many Puzzles and A Possible Explanation," Working Paper 11267, National Bureau of Economic Research, Cambridge MA, April. 
Harberger, A.C. (2006) "Taxation and Income Distribution: Myths and Realities," in J. Alm, J. Martinez-Vazquez and M.Rider, eds., The Challenges of Tax Reform in a Global Economy (New York: Springer).

Heady, C. (2004) "Taxation Policy in Low-income Countries," in T. Addison and A. Roe, eds., Fiscal Policy for Development: Poverty, Reconstruction and Growth (London: Palgrave).

Hettich, W. and S. Winer (1999) Democratic Choice and Taxation (Cambridge: Cambridge University Press).

Hirschman, A. (1970) Exit, Voice, and Loyalty (Cambridge, MA: Harvard University Press).

Hoffman, Barak D. and Clark C. Gibson (2006) "Political Accountability and Fiscal Governance: Evidence from Tanzania and Zambia." www.econ.ucsd.edu/seminars/0607seminars/gibson_paper.pdf.

Hughes, G. (1987) "The Incidence of Fuel Taxes: A Comparative Study of Three Countries," in D. Newbery and N. Stern, eds, The Theory of Taxation for Developing Countries (New York: Published for the World Bank by Oxford University Press).

Inter-American Development Bank (IDB) (2006) The Politics of Policies (Washington).

International Monetary Fund (IMF) (2006) "Fiscal Policy for Growth and Development: An Interim Report," DC2006-0003, Development Committee, April.

Kaldor, N. (1956) Indian Tax Reform (New Delhi: Government of India Ministry of Finance).

Kaldor, N. (1960) Suggestions for a Comprehensive Reform of Direct Taxation (Colombo).

Kaldor, N. (1963) "Will Underdeveloped Countries Learn to Tax?" Foreign Affairs, 41: 410-19.

Keen, M. (2006) "VAT Attacks! Second Best Perspectives on the Value Added Tax," Paper presented to International Institute of Public Finance, Cyprus, August 2006. 
Keynes, J.M. (1936) The General Theory of Employment, Interest and Money (New York: Harcourt, Brace).

Levi, M. (1988) Of Rule and Revenue (Berkeley: University of California Press).

Lieberman, E.S. (2003) Race and Regionalism in the Politics of Taxation in Brazil and South Africa (Cambridge: Cambridge University Press).

Lindert, P.H. (2003) Growing Public: Social Spending and Economic Growth Since the Eighteenth Century (Cambridge: Cambridge University Press).

Lindert, P.H. (2004) "Voice and Growth; Was Churchill Right?," Journal of Economic History, 63 (2): 315-50.

Lledo, Victor, Aaron Schneider, and Mick Moore (2003) "Pro-poor Tax Reform in Latin America: A Critical Survey and Policy Recommendations," IDS Report commissioned by DFID, March.

Lledo, Victor, Aaron Schneider, and Mick Moore (2004) "Governance, Taxes, and Tax Reform in Latin America," IDS Working Paper 221, Institute of Development Studies, Brighton.

Lora, E. and M. Cardenas (2006) "La reforma de las instituciones fiscales en América Latina," Inter-American Development Bank, Research Department, Documento de Trabajo \#559, April.

Martinez-Vazquez, J. (2001) "Mexico: An Evaluation of the Main Features of the Tax System," Working Paper 01-12, International Studies Program, Andrew Young School of Policy Studies, Georgia State University, November.

McIntyre, M. and O. Oldman (1975) Institutionalizing the Process of Tax Reform: A Comparative Analysis (Amsterdam: International Bureau of Fiscal Documentation).

McLaren, J., ed. (2003), Institutional Elements of Tax Design (Washington: World Bank).

McLure, C.E. (1999) "Tax Holidays and Investment Incentives: A Comparative Analysis," Bulletin for International Fiscal Documentation, 53 (8): 326-39.

Moore, M. (2004) "Taxation and the Political Agenda, North and South," Forum for Development Studies, No.1-2004: 7-32. 
Morrisset, J. and A. Izquierdo (1993) "Effects of Tax Reform on Argentina's Revenues," World Bank Policy Research Working Paper WPS 1192, September.

Norregaard, J. and T. S. Khan (2007) "Tax Policy: Recent Trends and Coming Challenges," IMF working paper WP/07/274, Washington, DC, December.

Persson, T. and G. Tabellini (2000) Political Economics: Explaining Economic Policy (Cambridge, MA: MIT Press).

Persson, T. and G. Tabellini (2003) The Economic Effects of Constitutions: What do the Data Say? (Cambridge, MA: MIT Press).

Poirson, H. (2006) "The Tax System in India: Could Reforms Spur Growth?" IMF Working Paper WP/06/93, Washington, DC, April.

Schneider, F. and R. Klinglmair (2004) "Shadow Economies Around the World: What Do We Know?" Working Paper No. 0408, Department of Economics, Johannes Kepler University of Linz, April.

Schumpeter, J.A. (1954) History of Economic Analysis (New York: Oxford University Press).

Shah, A. and J. Whalley (1990) "Tax Incidence Analysis of Developing Countries: An Alternative View," World Bank Economic Review, 5: 535-52.

Sokoloff, K.L. and E.M. Zolt (2005) "Inequality and Taxation: Evidence from the Americas on How Inequality may Influence Tax Institutions," Tax Law Review, 59 (2): 167-241.

Steinmo, S. (1993) Taxation and Democracy: Swedish, British, and American Approaches to Financing the Modern State (New Haven: Yale University Press).

Surrey, S.S. and P.R. McDaniel (1985) Tax Expenditures (Cambridge, MA: Harvard University Press).

Thirsk, W.R. (1997) Tax Reform in Developing Countries (Washington: World Bank).

Toye, J. (2000) "Fiscal Crisis and Fiscal Reform in Developing Countries," Cambridge Journal of Economics, 24 (1): 21-44.

Tridimas, G. and S.L.Winer (2004) "The Political Economy of Government Size," European Journal of Political Economy, 21 (3): 643-66. 
UN Millennium Project (2005) Investing in Development (New York).

Warlters, Michael and Emmanuelle Auriol (2005) "The Marginal Cost of Public Funds in Africa," World Bank Policy Research Working Paper No. 3679, August.

Webber, C. and A. Wildavsky (1986) A History of Taxation and Expenditure in the Western World (New York: Simon and Shuster).

World Bank (2003) Ukraine: Tax Policy and Tax Administration, Report No. 26221-UA, World Bank, Kyiv, March.

World Bank and International Finance Corporation (2008) Paying Taxes 2008. Washington, DC.

Yoingco, A.Q. (1976) "Tax Research: The Philippine Experience," Graduate School, Centro Escolar University, Manila, March. 